\title{
MCCUNE-ALBRIGHT SYNDROME (MAS)
}

\author{
Mardiati $^{1}$, Fury Maulina ${ }^{2}$ \\ ${ }^{1}$ SMF Ilmu Kesehatan Anak, Fakultas Kedokteran Universitas Malikussaleh, Aceh, Indonesia \\ ${ }^{2}$ Bagian Ilmu Kesehatan Masyarakat, Fakultas Kedokteran Universitas Malikussaleh, Aceh, Indonesia \\ Corresponding author : mardiati@unimal.ac.id
}

\begin{abstract}
Abstrak
McCune-Albright Syndrome (MAS) adalah suatu penyakit yang etiologinya adalah akibat mutasi gen guanine nucleotide binding alpha stimulating (GNAS1) pada masa embrionik. Mutasi gen GNAS1 ini terjadi pada masa kehamilan dan secara acak yang akan menghasilkan sebagian sel tubuh yang normal dan sebagian lainnya akan mengalami mutasi, fenomena ini yang disebut mosaicism. Sindrom ini memiliki tiga tanda klinis yaitu, displasia fibrosa, pigmentasi kulit (cafe-au-lait), dan disertai puibertas prekoks. Diagnosis MAS biasanya berdasarkan pemeriksaan klinis, radiografi, biopsi dan uji genetik. Aspek yang paling penting dari konseling kepada keluarga adalah untuk memberikan pengetahuan kepada keluarga bahwa penyakit ini tidak menular, juga tidak berhubungan dengan lingkungan atau dari kelompok etnis tertentu. Penatalaksanaan terhadap MAS adalah berdasarkan manifestasi klinis yang muncul dan membutuhkan kerjasama tim yang melibatkan bedah orthopedi, bedah plastik dan ahli endokrin.
\end{abstract}

Kata kunci: McCune-Albright Syndrome (MAS); guanine nucleotide binding alpha stimulating (GNAS1); cafe-au-lait; mutasi gen 


\title{
McCune-Albright Syndrome (MAS)
}

\begin{abstract}
McCune-Albright Syndrome (MAS) is a disease whose etiology is due to mutations in the guanine nucleotide binding alpha stimulating gene (GNAS1) during embryonic times. This mutation of the GNAS1 gene occurs during pregnancy and randomly produces some normal body cells and some others will mutate, this phenomenon is called mosaicism. This syndrome was defined by the triad of polyostotic fibrous dysplasia of bone (FD), café-au-lait skin pigmentation, and precocious puberty (PP). The diagnosis of MAS is usually based on clinical examination, radiography, biopsy and genetic testing. The most important aspect of counseling for families is to provide knowledge to families that the disease is not contagious, nor is it related to the environment or from certain ethnic groups. Management of MAS is based on emerging clinical manifestations and requires teamwork involving orthopedic surgery, plastic surgery and endocrinologists.
\end{abstract}

Keywords: McCune-Albright Syndrome (MAS); guanine nucleotide binding alpha stimulating (GNAS1); cafe-au-lait; gene mutation 


\section{PENDAHULUAN}

McCune-Albright Syndrome (MAS) merupakan sindrom yang jarang dan terjadi secara sporadik akibat kelainan genetik. ${ }^{1}$ Penyakit ini ditemukan pada tahun 1937 oleh Donovan James McCune dan Fuller Albright sebagai penyakit kelainan genetik yang melibatkan tulang, pigmentasi kulit dan pubertas prekoks. ${ }^{2}$ Sindrom ini lebih sering terjadi pada perempuan daripada laki - laki. ${ }^{3}$

Data lengkap mengenai prevalensi MAS belum diketahui, dari data yang ada diperkirakan prevalensi MAS sekitar 1/100.000 sampai 1/1.000.000. Sebaliknya, data mengenai kelainan rangka akibat MAS berupa displasia fibrosa telah banyak dilaporkan, diperkirakan lebih dari 7\% kasus tumor tulang jinak merupakan displasia fibrosa. ${ }^{4,5}$

Displasia fibrosa dapat melibatkan satu tulang rangka ataupun lebih dari satu, dengan gejala lemas dan sakit serta bisa disertai dengan fraktur. Skoliosis sering terjadi dan bersifat progresif. Selain pubertas prekoks pada laki - laki dan perempuan. Juga ditemukan kelainan endokrin yang lain berupa hipertiroidisme, hormon pertumbuhan yang berlebihan, sindrom cushing, dan gangguan fosfat di ginjal. Café-au-lait biasanya muncul pada periode neonatal, tetapi pubertas prekoks dan dislasia fibrosa yang paling sering membawa anak untuk mendapatkan perawatan medis. ${ }^{4}$

McCune-Albright Syndrome (MAS) terjadi akibat dari mutasi somatik gen guanine nucleotide binding, alpha stimulating (GNAS), khususnya mutasi pada protein cAMP pengatur, Gs alpha. Kelainan dari penyakit ini ditentukan oleh migrasi, proliferasi dan kelangsungan hidup sel yang bermutasi spontan selama perkembangan embrio. Diagnosis MAS biasanya berdasarkan pemeriksaan klinis. Radiografi sering membantu dalam menegakkan diagnosis displasia fibrosa dan biopsi dari lesi displasia fibrosa dapat membantu diagnosis. ${ }^{4}$ Prognosis dari MAS berhubungan dengan kelainan yang diakibatkan oleh displasia fibrosa yang melibatkan banyak tulang rangka dengan morbiditas mulai dari ringan sampai berat, dan kematian mendadak pernah dilaporkan terjadi akibat keterlibatan jantung. ${ }^{2}$

Tujuan penulisan refarat ini adalah untuk membahas secara ringkas mengenai definisi, etiologi, patogenesis, patofisiologi, diagnosis, manifestasi klinis, dan tatalaksana dari McCune-Albright Syndrome (MAS)

\section{DEFINISI DAN ETIOLOGI}

McCune-Albright Syndrome (MAS) secara klasik didefinisikan sebagai suatu penyakit yang memiliki tiga tanda klinis yaitu dysplasia fibrosa, pigmentasi kulit (cafe-au-lait), dan 
disertai gangguan pada kelenjar endokrin. ${ }^{3,4,5}$ Displasia fibrosa yang terjadi pada penyakit ini adalah berupa bentuk poliostotik displasia fibrosa, sedangkan gangguan endokrin yang dapat berasosiasi dengan penyakit ini adalah pubertas prekoks (pubertas dini, biasanya pada anak perempuan), hipertiroidisme, sindrom cushing, hipersomatotropisme, hiperprolaktinemia, hiperparatiroidisme, dan riketsia/osteomalasia. ${ }^{4,6}$ Suatu hal yang sangat jarang tetapi memiliki kemungkinan bahwa penyakit ini dapat melibatkan sistem organ tubuh lain seperti hati, jantung, kelenjar tiroid atau pankreas. ${ }^{5}$

Secara lebih singkat Collin dan Shenker mendefinisikan MAS sebagai displasia fibrosa yang disertai salah satu gangguan kelenjar endokrin yang telah disebutkan diatas dan adanya pigmentasi pada kulit yang berupa pigmentasi (Cafe-au-lait spot). ${ }^{6}$

Etiologi dari penyakit ini secara molekuler adalah adanya mutasi pada regulasi protein Gas yang terjadi pada gen GNAS1. ${ }^{7,8}$ Mutasi gen GNAS1 ini terjadi secara acak pada masa kehamilan yang akan menghasilkan sebagian sel tubuh yang normal dan sebagian lain mengalami mutasi, fenomena ini yang disebut mosaicism. ${ }^{7,9}$ Keparahan penyakit ini beserta kelainan yang menyertainya tergantung pada jumlah dan lokasi dari sel yang mempunyai gen GNAS yang telah bermutasi. ${ }^{7}$

Nama lain dari McCune-Albright Syndrome (MAS) ini adalah : ${ }^{7}$

1. Albright-McCune-Sternberg Syndrome

2. Albright's disease

3. Albright's disease of bone

4. Albright's Syndrome

5. Albright's syndrome with preconius puberty

6. Albright-Stenberg syndrome

7. Polyostotic Fibrous Dysplasia

8. Fibrous dysplasia with pigmentary skin and precocius puberty

9. Osteitis fibrosa disseminata

\section{Patogenesis}

Gen GNAS memberikan suatu instruksi untuk membentuk satu komponen yaitu subunit alpha stimulasi dari kompleks protein yang disebut guanine nucleotide-binding protein (protein $\mathrm{G}$ ). Protein $\mathrm{G}$ dikode oleh beberapa gen yaitu gen $16 \alpha$, gen $6 \beta$, dan gen $12 \gamma$. Apabila terjadi defek pada protein $\mathrm{G}$ dapat menyebabkan terjadinya penyakit dengan 
beberapa cara yaitu, pertama protein G tidak bisa menghidrolisis GTP (guanine triphospate), kedua protein $\mathrm{G}$ tidak dapat menghentikan stimulus yang berakibat terjadinya peningkatan aktifitas efektor, walaupun tidak ada stimulus dari luar. Penurunan produksi protein $\mathrm{G}$ secara normal atau terbentuknya protein $G$ yang tidak stabil dapat mengurangi respon normal terhadap stimulasi hormon. Protein G mempunyai beberapa subunit yang salah satunya

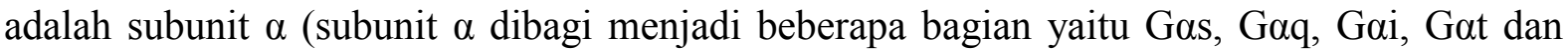
lainnya). Masing - masing subunit tersebut mempunyai fungsi berbeda dalam menghantarkan sinyal. $^{10}$

Pada MAS, protein G yang mengalami mutasi adalah gen GNAS1 yang merupakan subunit dari Gas. Gen GNAS1 terletak pada kromosom 20q13.1-13.2, jika terjadi mutasi pada gen GNAS1 ini maka akan meningkatkan atau menurunkan aktifitas dari sistem yang terkait pada tingkat interaksi hormon dengan reseptor. ${ }^{10}$

Pada pasien MAS ditemukan adanya mutasi pada exon 8 pada gen GNAS1 yang berasal dari jaringan yang terinfeksi. Mutasi yang terjadi dimana dua asam amino, histidin dan sistein digantikan oleh arginin di posisi 201 pada gen Gas. Dalam keadaan yang lebih jarang arginin digantikan oleh serin, glisin, atau leusin. ${ }^{4,11}$

Penelitian yang lain menemukan adanya mutasi pada 49 orang dari 113 pasien MAS. Pada pasien MAS mutasi pada sel yang terkait akan mempengaruhi jaringan tulang, kulit, dan endokrin. Mutasi juga dapat ditemukan pada organ lain yang secara langsung tidak terlibat seperti darah, hati dan jantung. ${ }^{12}$ Mutasi pada Gas bertanggung jawab terhadap terjadinya peningkatan produksi cAMP., ${ }^{9,12}$ Patogenesis dari sindrom ini lebih diarahkan kepada proses yang terjadi secara molekuler, sedangkan patofisiologi dari sindrom ini lebih diarahkan pada perubahan yang ditimbulkan akibat proses patogenesis. ${ }^{12}$

\section{Patofisiologi}

Proses perjalanan penyakit MAS dipengaruhi oleh beberapa hormon yaitu :,5

\section{MSH (melanocyte stimulating hormone)}

Melanocyte stimulating hormone (MSH) berperan dalam proses terjadinya pigmentasi kulit café-au-lait.

\section{LH (leutinizing hormone)}

Hormon ini berperan dalam proses terjadinya masalah pubertas prekok atau pubertas dini yang

banyak terjadi pada anak perempuan. 


\section{TSH (thyroid stimulating hormone)}

Hormon tiroid ini berperan dalam proses terjadinya hipertiroidisme.

4. GHRH (growth hormone, stimulating hormone)

Displasia fibrosa merupakan temuan klinis yang paling sering muncul pada pasien dengan

MAS, proses terjadinya berkaitan dengan hormon GHRH ini.

\section{ACTH (adrenocrotical stimulating hormone)}

Penyakit pada pasien MAS yang berkaitan dengan hormon ini adalah sindrom cushing.

Hormon - hormon tersebut akan berinteraksi dengan protein $G$ khususnya subunit alpha. Pada penderita MAS terjadi mutasi pada subunit alpha yang menginduksi AC (adenylate cyclase), sehingga akan terbentuk kadar cAMP yang tinggi di intraselular. Proses ini akan menyebabkan tingginya produksi melanin, estradiol, testosteron, tiroksin, hormon pertumbuhan, dan kortisol (Gambar1). ${ }^{4}$

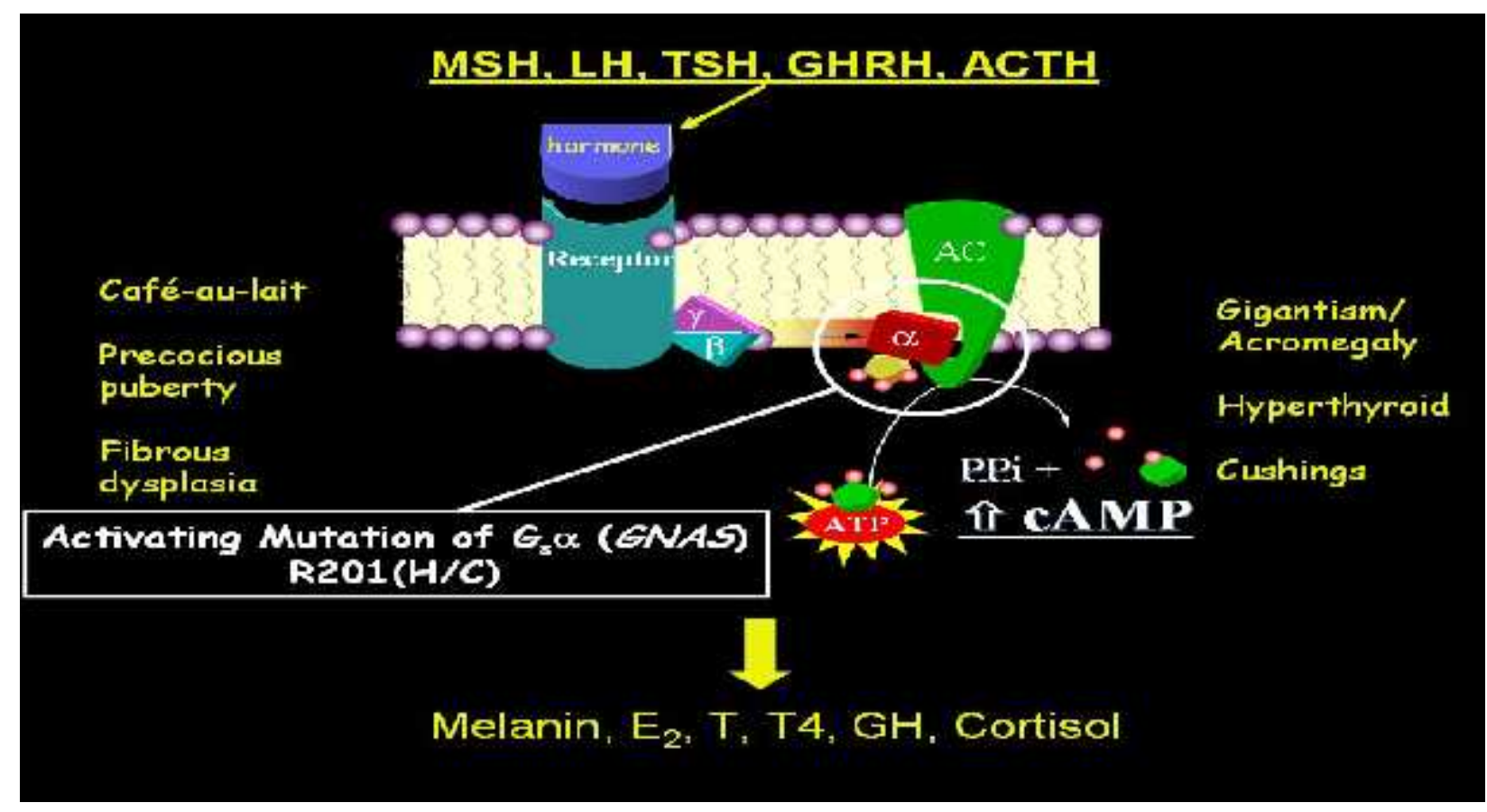

Gambar 1. Patofisiologi Sindrom McCune-Albright secara molekular., ${ }^{4,5}$

Disregulasi produksi dari hormon - hormon tersebut akan menghasilkan pigmentasi café-au-lait, pubertas prekok, fibrous displasia, akromegali, hipertiroidisme, dan Sindrom Chusing yang tergantung pada jaringan yang mengandung mutasi somatis (gambar 2). ${ }^{4}$ 


\section{The molecular and embryological explanation of McCune-Albright Syndrome}

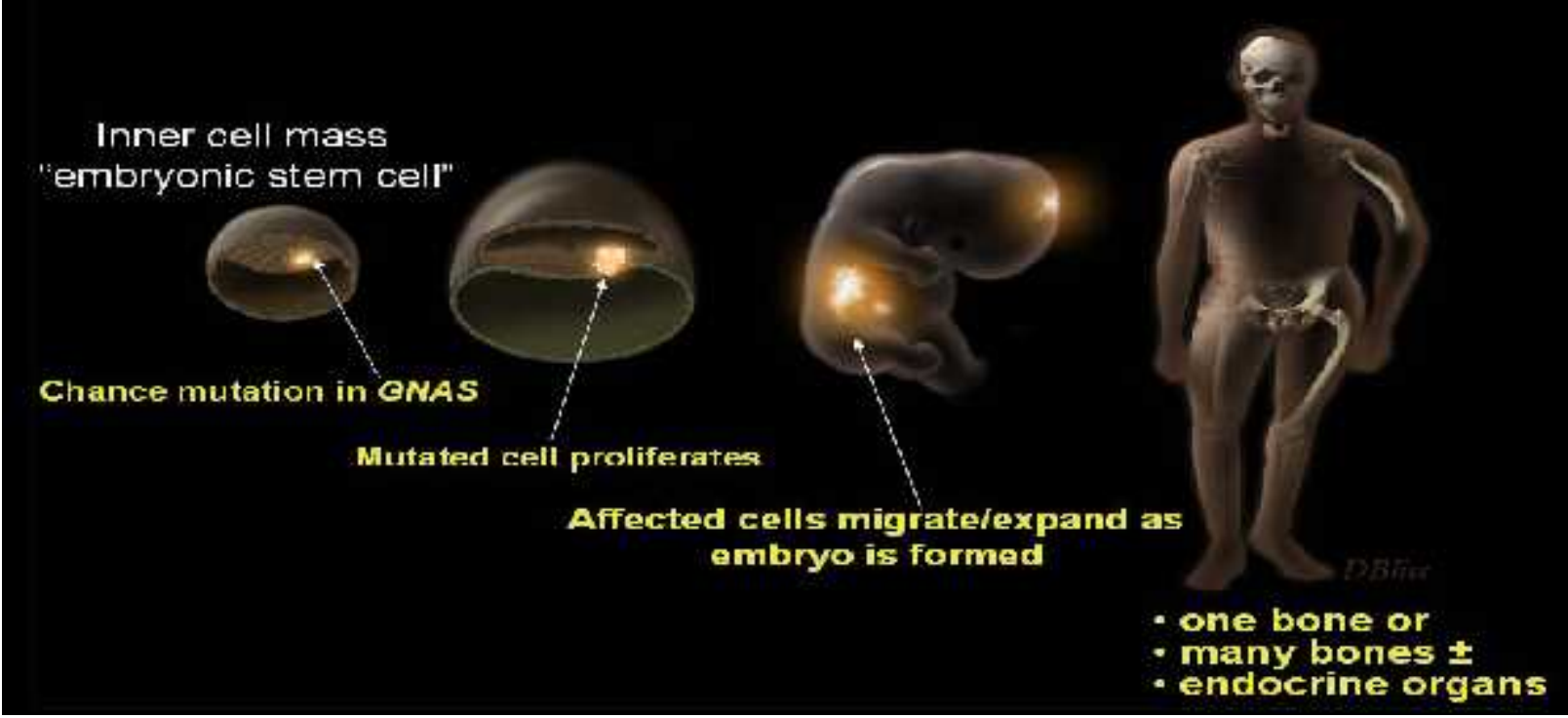

Gambar 2. Penjelasan Sindrom McCune-albright secara molekuler dan embriologi. ${ }^{4,5}$

\section{Diagnosis}

Diagnosis dari MAS dapat ditegakkan melalui beberapa cara yaitu :,5

- Pemeriksaan Klinis

- Radiografi

- Biopsi

- Uji Genetik

\section{Pemeriksaan Klinis}

Pada pemeriksaan klinis kelainan yang dapat ditemukan adalah, gangguan pada kelenjar endokrin (pubertas prekoks, hipertiroidisme, sindrom chusing, dll) pigmentasi pada kulit dan displasia pada tulang. ${ }^{4,5}$

\section{Radiografi}

Gambaran radiografi sangat membantu untuk menegakkan diagnosa terhadap dysplasia fibrosa yang merupakan temuan klinis pada sindrom ini. Displasia fibrosa secara radiografi mempunyai gambaran khas yang disebut ground glass. ${ }^{4,5}$

Secara umum gambaran radiografi dysplasia fibrosa pada setiap tulang berbeda. Pada tulang panjang, lesi ini akan cendrung terlihat "litik", sedangkan pada tulang kraniofasial lesi cendrung terlihat "sklerotik". Hal ini berkaitan dengan proses mineralisasi dalam jumlah yang relatif lebih besar dari jaringan dysplasia fibrosa pada tulang kraniofasial. Gambaran 
computed tomografi ( CT-Scan) adalah teknik yang paling baik dalam mendiagnosa lesi dysplasia fibrosa pada tulang tengkorak. Gambaran CT-scan pada anak-anak akan terlihat homogen, sedangkan pada pasien lansia akan terlihat seperti kista pada beberapa area, meskipun gambarannya seperti kista tetapi bukanlah suatu kista yang sebenarnya., ${ }^{4,5}$

\section{Biopsi}

Apabila dari hasil pemeriksaan radiografi belum dapat ditegakkan diagnosa terhadap dysplasia fibrosa, maka dapat dilakukan biopsi pada jaringan yang terinfeksi. Gambaran histopatologi dari displasia fibrosa sering digambarkan sebagai sebuah pola "chinese writing" dan dengan persiapan dan pewarnaan khusus dapat mendeteksi bukti adanya osteoid yang termineralisasi dan tidak termineralisasi. ${ }^{4,5}$

\section{Uji Genetik}

Uji genetik memungkinkan untuk dilakukan, akan tetapi tidak tersedia secara rutin. Karena somatic mosaic nature dari penyakit MAS, akan memberikan hasil yang negatif pada jaringan yang ada tanpa mengesampingkan kemunculan dari mutasi. Pada kebanyakan kasus, uji genetik memberikan sedikit kontribusi dalam mendiagnosis dan tidak seluruhnya dapat dimanajemen. Korelasi genotip/fenotip tidak diketahui, dengan demikian pengetahuan mengenai mutasi spesifik tidak memiliki pengaruh terhadap perawatan. Untuk alasan inilah, maka ketika diagnosis MAS ditegakkan, penting untuk menyadari luas jaringan yang mungkin terlibat, Skrining (pemeriksaan yang cepat), secara minimal memerlukan catatan medis dan pemeriksaan fisik dan biasanya memerlukan gambaran khas dan uji biokimia. ${ }^{4,5}$

\section{Manifestasi klinis}

Beberapa manifestasi klinis dari sindrom ini adalah berupa $:^{4,5}$

a. Gangguan pada kelenjer endokrin

b. Pigmentasi pada kulit

c. Displasia pada tulang

\section{A. Gangguan Pada Kelenjar Endokrin}

Pada kelenjar endokrin akan terdapat beberapa keadaan yaitu, pubertas prekoks, hipertiroidisme, Sindrom Cushing, hipersomatotropism, hiperprolaktinemia, akromegali, hiperparatiroidisme, dan riketsia/osteomalasia, Tetapi dalam bagian ini yang akan dijelaskan hanya pubertas prekok, hipertiroidisme, dan Sindrom Cushing. ${ }^{4,5}$

\section{Pubertas Prekoks}

Pubertas prekoks atau pubertas dini sejauh ini adalah manifestasi yang paling sering pada pasien MAS., khususnya pada perempuan. Pubertas prekoks ini terjadi akibat adanya aktifitas 
dari luteinizing hormon (LH). Dari hasil penelitian Benedict ditemukan bahwa hampir sepertiga wanita yang menderita MAS mengalami pubertas prekoks. ${ }^{5}$

Keadaan yang terjadi pada pasien perempuan yang mengalami pubertas prekoks ini adalah menstruasi yang datang tiba-tiba, yang mengakibatkan perdarahan pada vagina yang terjadi pada waktu usia satu tahun kelahiran. Keadaan lain yang terjadi pada perempuan dengan sindrom ini adalah tidak adanya rambut kemaluan atau jumlahnya yang lebih sedikit dari yang normal. Penderita MAS perempuan yang mengalami pubertas prekoks ini memiliki faktor predisposisi yang tinggi terhadap resiko terjadinya kanker payudara. ${ }^{11}$

Pada anak laki-laki yang menderita MAS, pubertas prekoks ini jarang dijumpai. Pada lakilaki, pubertas prekoks ini berkembang lebih lambat daripada wanita yaitu antara usia 4 dan 9 tahun. Manifestasi klinis yang paling sering ditemukan adalah terjadinya pembesaran pada penis dan testis yang diikuti oleh pertumbuhan rambut pubis. ${ }^{11}$

\section{Hipertiroidisme}

Hipertiroidisme adalah kelainan pada kelenjar endokrin yang sering ditemukan pada pasien MAS. Hipertiroidisme pada sindrom ini terjadi akibat mutasi protein $\mathrm{G}$ pada tingkat thyroid stimulating hormone (TSH). Pada pasien MAS, hipertiroidisme ditemukan pada semua usia. Keadaan klinis yang terlihat pada pasien MAS yang mengalami hipertiroidisme adalah terjadinya pembesaran kelenjar tiroid. ${ }^{5}$

\section{Sindrom cushing}

Sindrom cushing adalah kelainan yang terjadi akibat produksi yang berlebihan dari hormon kortisol. Sindrom Cushing dapat terjadi pada periode neonatal, namun belum pernah dilaporkan melewati usia 1 tahun pertama. Beberapa kasus cushing neonatal bisa sembuh secara spontan. Sindrom cushing harus dipertimbangkan dan diskrining pada pasien - pasien yang berusia muda. Pemeriksaan fisik biasanya didapatkan moon face, hirsutisme, dan berkurangnya pertumbuhan linier. ${ }^{4}$ 


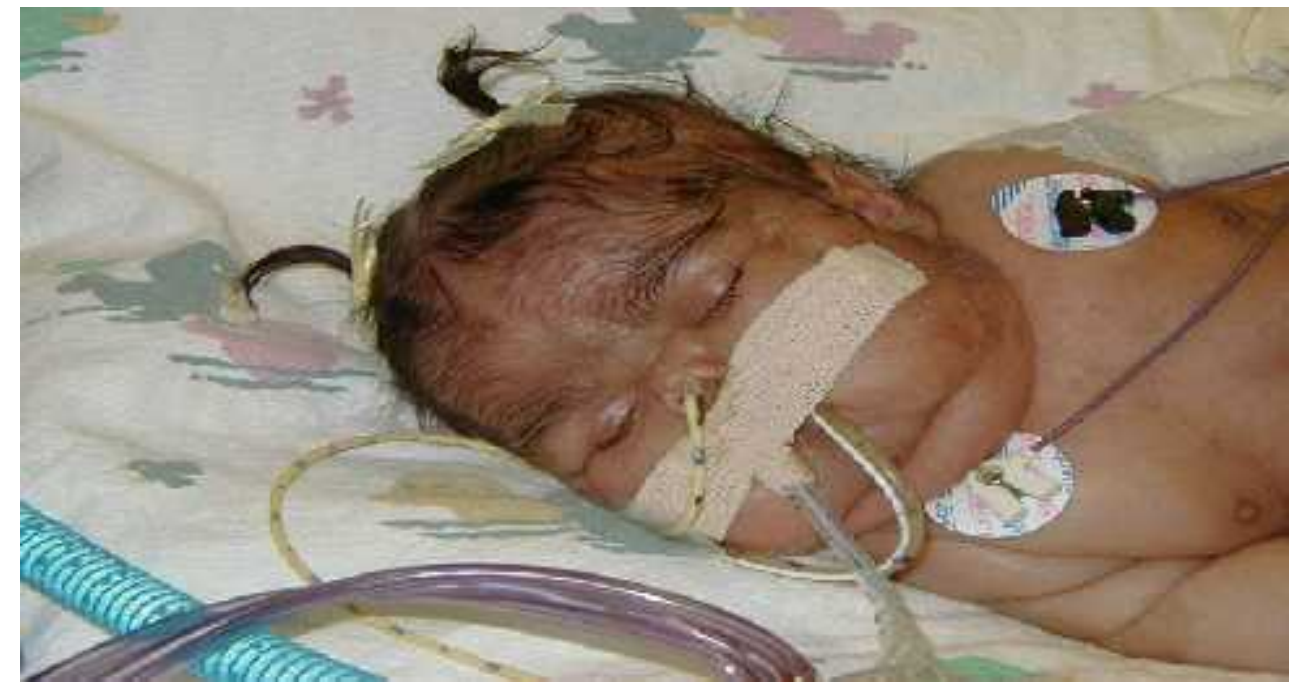

Gambar 3. Anak penderita MAS dengan sindrom cushing. ${ }^{4}$

\section{B. Pigmentasi pada kulit}

Karakteristik lesi kulit pada pasien MAS adalah adanya makula café-au-lait tetapi hal ini bukan tanda klinis yang utama dalam menentukan diagnosis. Bercak ini bisa muncul saat lahir dan segera setelah lahir, khas dari bercak kulit ini adalah warnanya seperti coklat susu. Pada anak kulit putih mudah untuk diidentifikasi sedangkan pada anak yang memiliki kulit agak gelap hal ini sulit untuk terlihat. ${ }^{11,13}$

Pola distribusi pigmen pada kulit ini sangat unik, sering dimulai atau berakhir tibatiba di garis tengah tubuh, baik pada bagian depan seperti dada dan perut ataupun di tulang belakang. Beberapa anak tidak memiliki pigmen cafe-au-lait sama sekali, pada beberapa anak terbatas didaerah yang kecil, seperti di leher atau lipatan bokong. Jarang ada masalah medis yang terkait dengan macula cafe-au-lait ini. Tempat yang biasa terdapat makula café-au-lait adalah daerah kepala, leher, area sakral, dan panggul. ${ }^{13}$ 


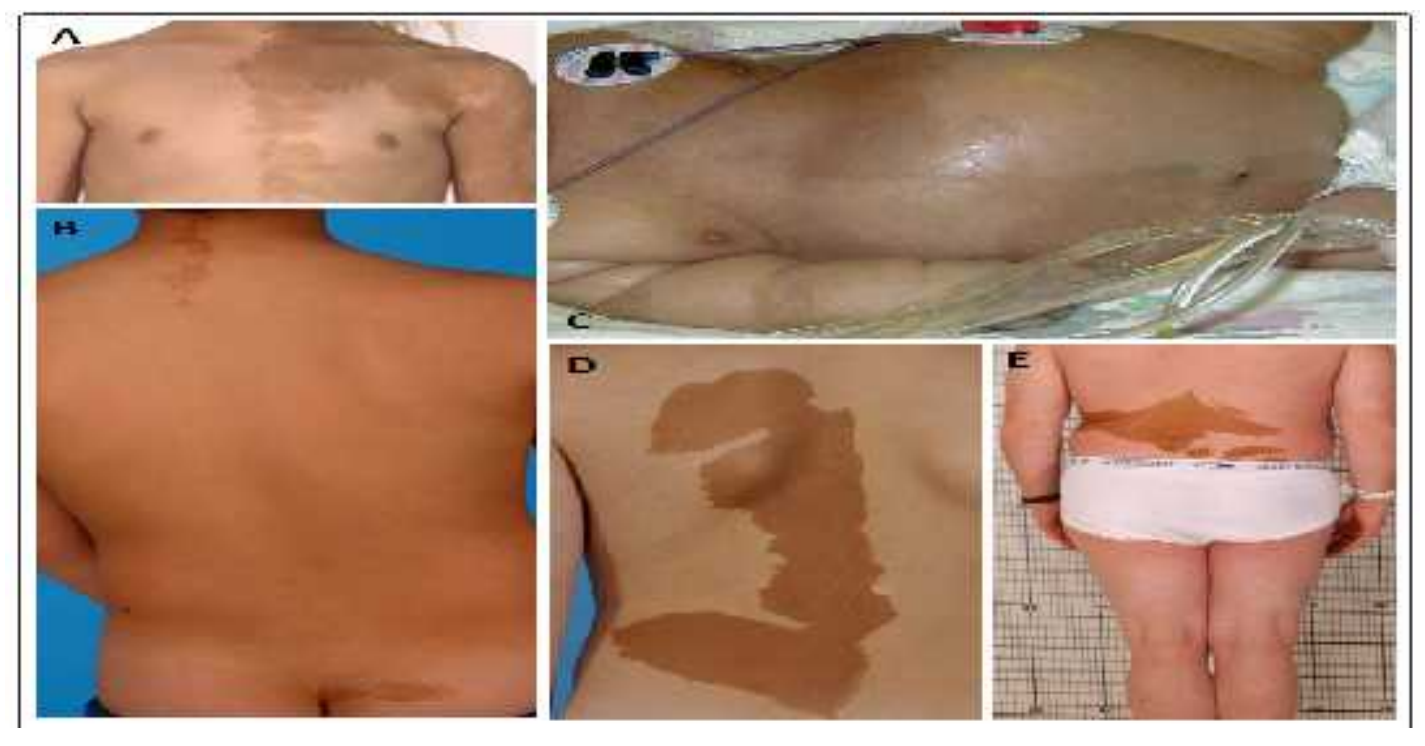

Gambar 4. Gambaran café-au-lait pada MAS. ${ }^{11}$

\section{Displasia pada tulang}

Selain adanya bentuk pigmentasi café-au-lait dan aktifitas yang berlebihan pada beberapa organ dari kelenjar endokrin, displasia fibrosa pada tulang adalah manifestasi utama pada MAS. ${ }^{6,13}$ Lesi displastik ini ditandai dengan pergantian yang progresif dari jaringan tulang yang normal menjadi jaringan fibroosseus yang abnormal. Perluasan lesi ini menyebabkan fraktur patologis, kerapuhan tulang, nyeri dan kompresi pada syaraf. Fraktur tulang yang paling sering terjadi adalah pada tulang femur, tibia, humerus dan lengan bawah. Tetapi sangat disayangkan keadaan ini tidak terdeteksi dalam waktu yang lama. ${ }^{13}$

\section{Penatalaksanaan}

Pengobatan khusus terhadap MAS tidak ada, penatalaksanaan terhadap manifestasi klinis yang muncul dapat berupa: ${ }^{14}$

- Obat untuk mengatasi rasa sakit

- Pembedahan untuk memperkuat tulang yang terkena dengan cangkok tulang atau dengan pemakaian gips

- Pemberian obat bifosfonat untuk mencapai kepadatan tulang

- Pemberian suplemen vitamin D untuk mengurangi risiko rakhitis

- Pembedahan untuk mengangkat kista ovarium

- Pembedahan untuk mengangkat kelenjar adrenal yang abnormal pada kasus sindrom cushing

- Terapi hormon atau operasi untuk mengobati tumor hipofisis

- Terapi hormon atau operasi untuk mengobati gigantisme. 
- Terapi untuk pubertas prekoks pada anak perempuan dengan perdarahan vagina adalah dengan pemberian aromatase inhibitor berupa: ${ }^{4}$

- Testolactone dengan dosis $40 \mathrm{mg} / \mathrm{kg} / \mathrm{hari}$ dengan dosis terbagi tiga

- Letrazole dengan dosis 2,5 mg/hari.

- Anastrazole dengan dosis $1 \mathrm{mg} /$ hari.

- Tamoxifen, studi menunjukkan bahwa tamoxifen mungkin bermanfaat dalam pengobatan pubertas prekoks pada MAS jangka panjang meskipun dengan data keamanan yang kurang, tetapi tamoxifen lebih efektif dalam memperlambat pematangan usia tulang.

- Terapi untuk pubertas prekoks pada anak laki-laki bertujuan untuk mencegah bertubuh pendek

dan mengontrol masalah perilaku yang berhubungan dengan kelebihan androgen. Obatobatan

dan dosis yang digunakan untuk mencegah tubuh pendek pada anak laki-laki adalah sama

seperti yang digunakan pada anak perempuan (lihat di atas, kecuali tamoxifen). Obatobatan

yang digunakan untuk mengobati gejala kelebihan androgen adalah berupa: ${ }^{4}$

- Spironolactone dengan dosis 5-7 mg/ kg/hari dengan dosis terbagi dua

- Flutamide dengan dosis $10 \mathrm{mg} / \mathrm{kg} / \mathrm{hari}$ dengan dosis terbagi dua.

Penatalaksanaan terhadap pasien ini membutuhkan kerjasama tim dari bedah orthopedi untuk mengatasi masalah yang berhubungan dengan tulang, bedah plastik untuk mengatasi masalah kelainan yang terjadi pada wajah dan ahli endokrin untuk penatalaksanaan ketidakseimbangan hormonal yang terjadi. ${ }^{14}$

\section{Diagnosis Banding}

Diagnosis banding dari MAS antara lain, pseudohypoparathyroidism dimana terjadi mutasi pada gen yang sama tetapi mengalami penurunan aktivitas pada protein Gs alpha. ${ }^{3}$ MAS sering dibingungkan juga dengan penyakit neurofibromatosis yang memiliki kelainan kulit yang sama berupa café au lait tetapi dapat dibedakan dari lokasi tersering ditemukan. Osteofibrous dysplasia merupakan lesi yang hampir sama dengan displasia fibrosa pada MAS tapi berbeda karena lebih sering ditemukan pada tibia dan fibula. Non-ossifying fibroma juga 
hampir mirip dengan dysplasia fibrosa pada MAS tetapi dapat dibedakan dengan pemeriksaan lanjutan berupa pemeriksaan radiologi dan histologi. ${ }^{5}$

\section{KONSELING GENETIK}

Aspek yang paling penting dari konseling kepada keluarga adalah untuk meyakinkan mereka bahwa penyakit ini tidak menular, juga tidak berhubungan dengan lingkungan atau dari kelompok etnis tertentu. Oleh karena itu, orang tua tidak perlu merasa "bertanggung jawab" atau bersalah karena anaknya menderita penyakit ini, dan pasien dapat yakin mereka tidak akan menularkan penyakit kepada keturunannya. ${ }^{5}$

\section{PROGNOSIS}

McCune-Albright Syndrome (MAS) bisa bermanifestasi secara dini sebagai kelainan hepatobilier dengan melibatkan jantung dan melibatkan organ lainnya selain organ endokrin, sehingga dapat mengakibatkan kematian mendadak atau kematian di usia dini. Jumlah keterlibatan tulang dan perubahan yang terjadi secara lambat laun akan mempengaruhi pertumbuhan anak. Harapan hidup bisa normal secara keseluruhan, tetapi pada beberapa pasien kelainan pada tulang bisa berkembang menjadi sarcoma ketika dewasa. ${ }^{3}$

\section{Referensi}

1. Tadmouri GO, Nair P. McCune-albright syndrome, Centre for Arab Genomic studies. 2006; $1-2$

2. Disease Alphabet. Albright's Syndrome: Symptoms, Causes, Diagnosis, Prognosis \& Treatment of Albright's Syndrome. Diunduh dari http://www.iamunwell.com Diakses Januari 2013

3. Wiedemann HR, Kunze J, Grosse FR. Clinical syndromes. Edisi ketiga. Mosby-Wolfe; 1997.h.360-1

4. Dumitrescu CE, Collins MT. McCune-albright syndrome. Orphanet Journal of Rare Diseases. 2008; 3:1-12

5. Collins MT. McCune-albright syndrome. Orphaned journal of Rare Diseases 2004: 1-17

6. Chapurlat RD. Fibrous dysplasia of bone and McCune-albright syndrome. Best Practice \$ Research Clinical Rheumatology. 2008; 22: 55-69

7. U.S. National Library of Medicine. McCune-albright syndrome. Diunduh dari: http://www.ghr.nlm.nih.gov Diakses Januari 2013

8. Westwood M. Principles of hormone action. Dalam: Brook CGD, Clayton PE, Brown RS, Savage MO, penyunting. Clinical Pediatric Endocrinology. Edisi kelima. Blackwell Publishing; 2005.h.1-17

9. Kopp P. Genetics, genomics, proteomics, and bioinformatics. Dalam: Brook CGD, Clayton PE, Brown RS, Savage MO, penyunting. Clinical Pediatric Endocrinology. Edisi kelima. Blackwell Pubishing; 2005.h.18-33 
10. U.S. National Library of Medicine. GNAS. Diunduh dari: http://www.ghr.nlm.nih.gov Diakses Januari 2013

11. Collins MT, Singer FR, Eugsteer E. McCune-albright syndrome and extraskeletal manifestations of fibrous dysplasia. Orphanet Journal of Rare Diseases. 2012; 7:1-14

12. Lumbroso S, Paris S, Sultan C. Activating Gsa mutations: analysis of 113 patients with signs of McCune-albright ayndrome - a European collaborative study. JCEM. 2004; $89: 2107-13$

13. MedicineNet.Com. Definition of McCune-albright syndrome. Diunduh dari: http://www.medterms.com Diakses Januari 2013

14. Better Health channel. McCune-albright syndrome. Diunduh dari: http://www.betterhealth.vic.gov.au Diakses Januari 2013 